さ異勾経訳收、い訳蔵本目

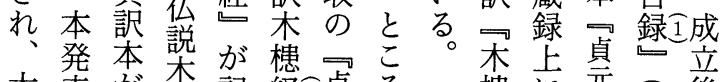

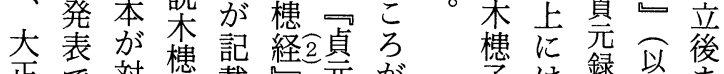

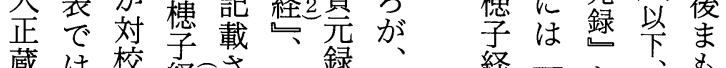

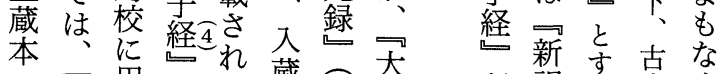

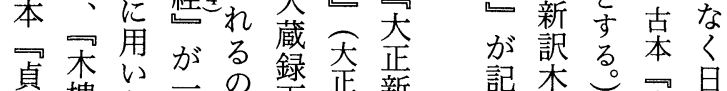

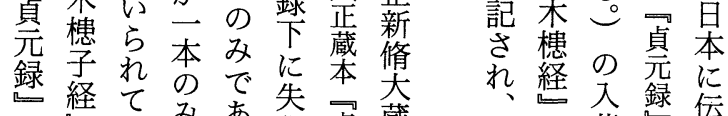

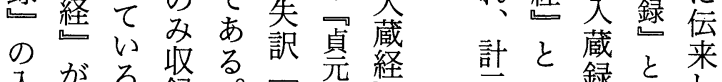

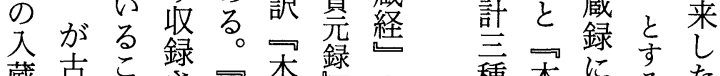

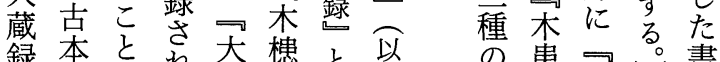

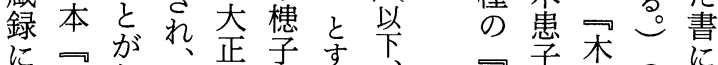

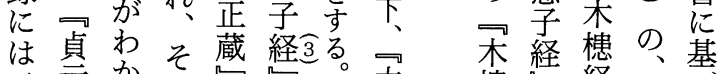

ば
に

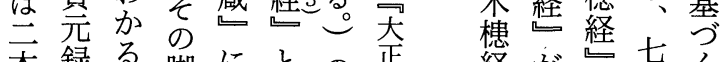

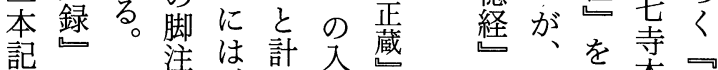

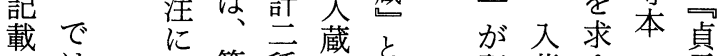

さは は第種録卞記蔵め完

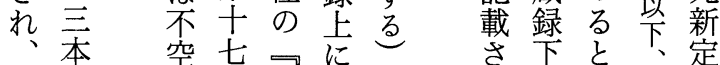

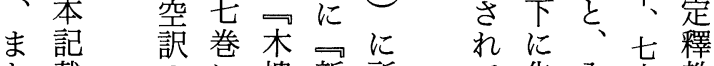

た載のに槵新所 て失入寺教

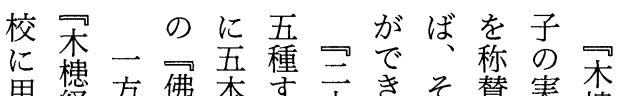

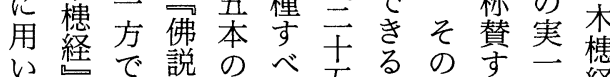

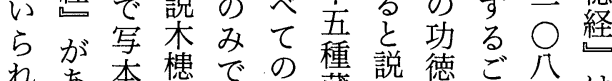

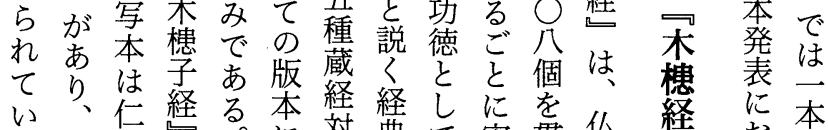

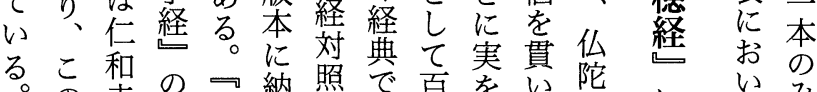

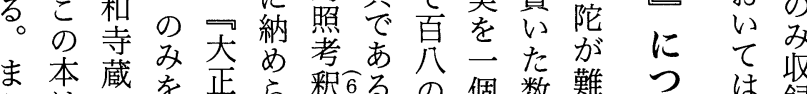

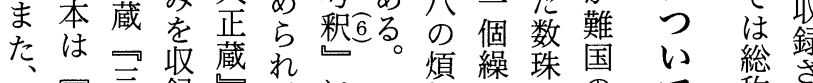

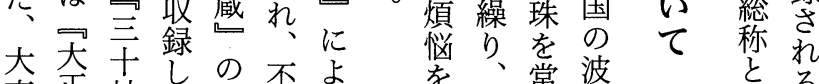

東正帖し、場空れ 滅こ常波 急蔵冊不合空 れ゙訳隇れ局璃

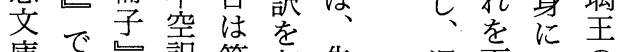

庫で異訳第收失涅百つの

に巷のは録訳槃方け求

は本十收七録乙訳遍、め

不二七録巻る罙到繰仏に

空つ帖しに版槵達り法応

訳とにて東本経息返僧心゙

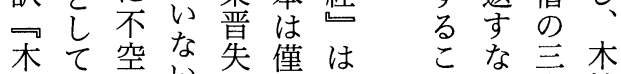

とるれ 木

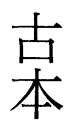

印

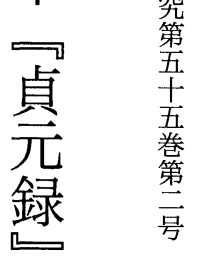

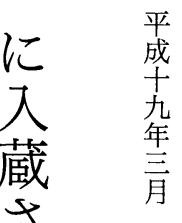

れ

た

種

の

采

槵

経

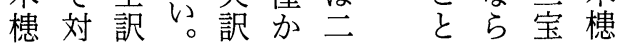




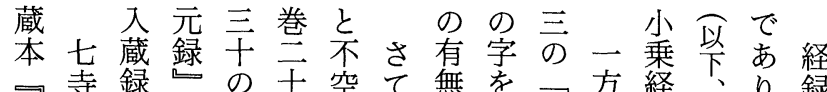
古口寺録包の十空て無を一方経、り録 点貞本下の入九訳、皆経典開、制で

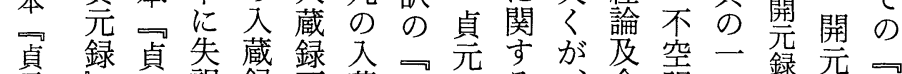

元元訳録下蔵木+る念訳っ録十木

録に録寺上録槵六説失誦のと飞八槵 に見心槵は訳に経年盟訳法杂でる年経

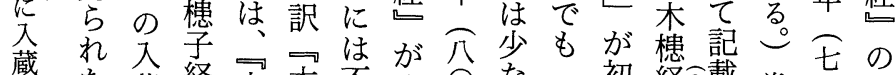

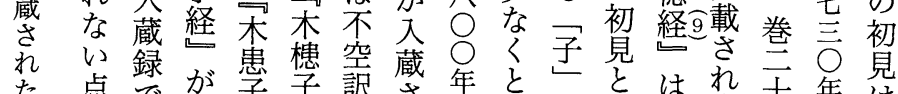

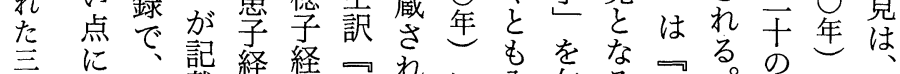
のい杰さとが訳る゙成蔵く場不唐蔵成の

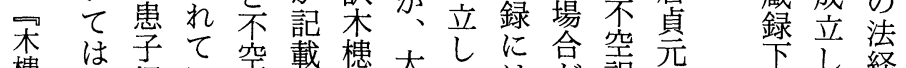

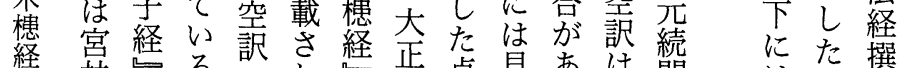
経喿勧る訳さ経正貞見あは簡はた撰 に昭の。新監坖らる。経元東開の つ彦経譯寺㒻本録なこ名釉晋元衆

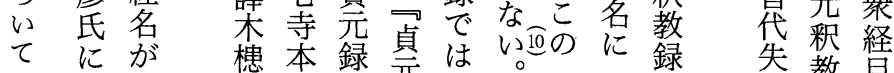

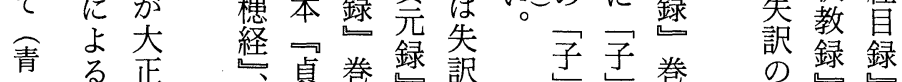

$$
\begin{aligned}
& \text { さたさ経 } \\
& \text { 写てが } \\
& \text { 、 七本い蔵 } \\
& \text { 入寺がるさ } \\
& \text { 蔵は剛うれ } \\
& \text { 録失寺にお } \\
& \text { に 訳興平り } \\
& \text { け不聖安 } \\
& \text { る 空寺時杲 } \\
& \text { 条䛒石か現 } \\
& \text { 槵言山鎌八 } \\
& \text { 経 所寺鏳 種 } \\
& \text { 蔵新時场 } \\
& \text { にさ秥代切 } \\
& \text { 机定に経 } \\
& \text { いる。方対 } \\
& \text { 二 照 } \\
& \text { 本て目 } \\
& \text { ず書 録卫 } \\
& \text { 写 } \\
& \text { 所さに }
\end{aligned}
$$

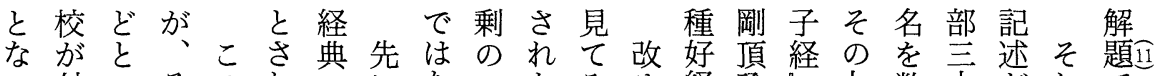
つ付のそのれのにな一たみめ経瑜止七数干卋れで

てさ対の経るう宮い本経るて伽吕寺先巻に指 いれ校実典経ち林かを典と七の他交本るのるょ摘 る。を数は典、氏と求の、寺交化称六と相がれさ い見は土の攵がすめ寒こ本部自師四七異、ばれ

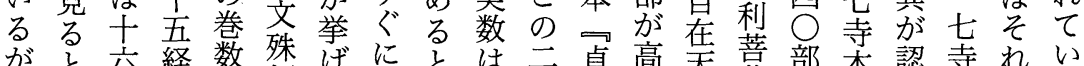

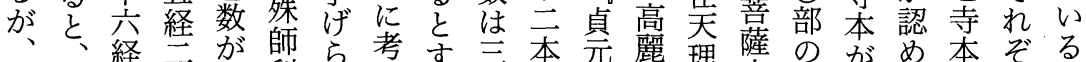

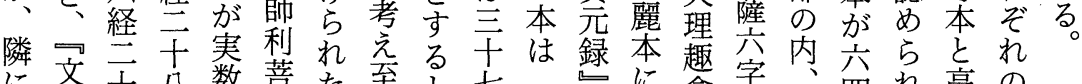

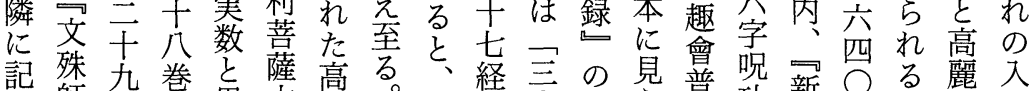

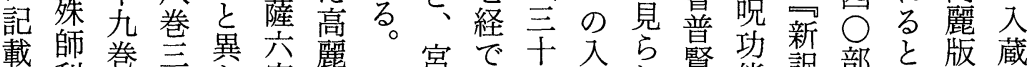

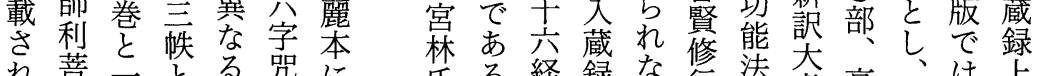

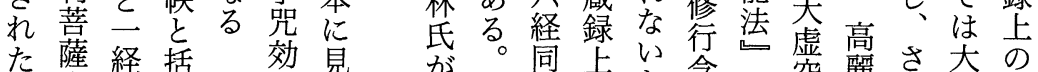
た薩経括効見㤎。同上い念二空麗さ大の 字咒多る 垽机摘至々本摘義乘菩がに経首

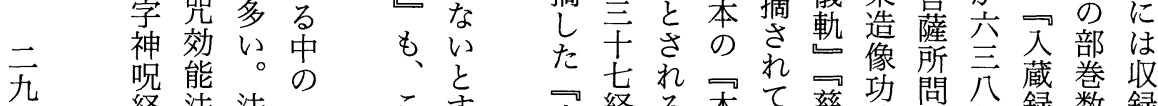

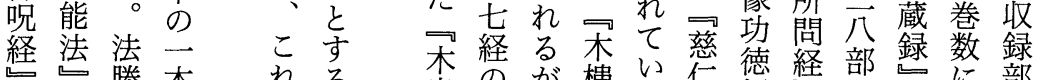

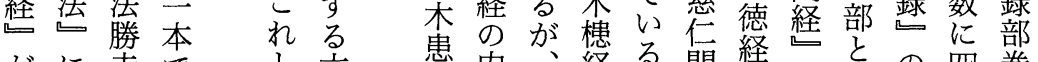
がに寺でと六息内、経る。問経年なの四巻 無は本あ同本経に記背年な経士数 点対なる帙の経余載を十金患り典五の 
本の打良

で七 $\neg$ り平国 あ寺木、安際 る。槵そ克仏 こ俥経調写経学 のの が查研 大 三現で究学 本李存七拠 院 の槵守寺点大 内経るにの学 容造 こ形で ははと口成は ほ何が貞学 ぼれ分元に術 同もか録お方 じ平つ心い口 で安たにてシ 大代載索イ き後さ経ア な期㫟調 推 違書た查進 い写通を事 はの 亭行業 経豊竞種て奈

たては説対七る兄改恶字方字神無楍こ

三思明校寺も蔵め記㫴に呪く効の 異す本本の録て元呪記経法能経 訳るにコの、のてて呪さ非勝法典 の注無貞口対条注経れに寺造严 種並記か見噺校槵記がたは本の場 の記はっ録訳を経がが注てに経合

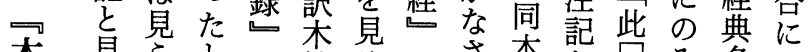

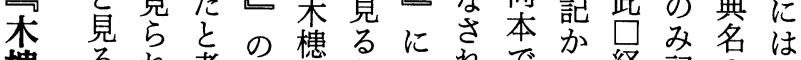
槵るるれ考底経とつ杂でら経記の詳

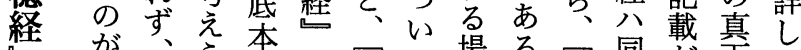

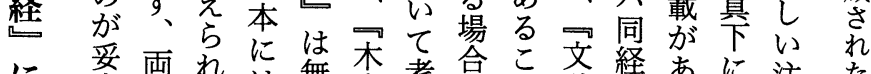

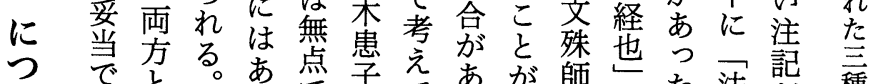

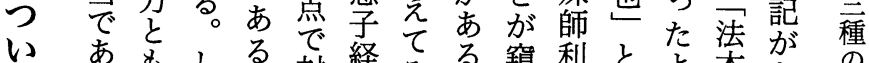

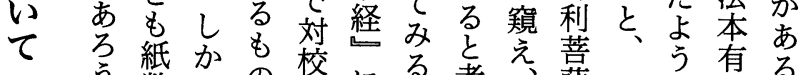

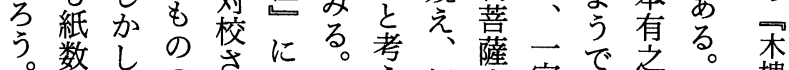

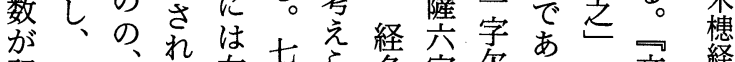
記こって右寺ら名字等ると文経 載の新い点寺势嵒損。記殊

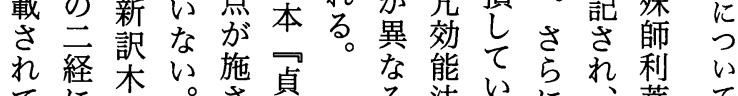

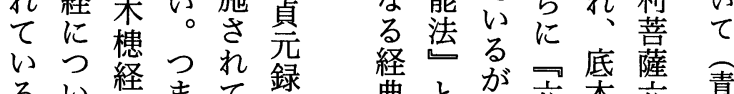
青

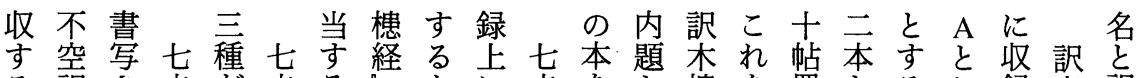
る。訳さ寺恃る加に寺をと槵を䍏とるし録者訳

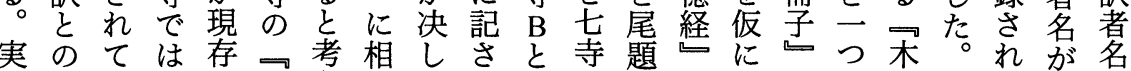

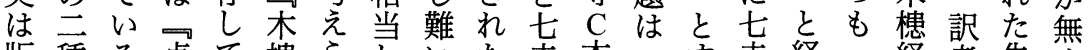
版種る貞て槵らしいた寺本一寺経二経者失〈冒 本のが元い経れ、が口C と新る B 典致名訳経頭 大斗録る造る七新はし譯経々名しはをの名部

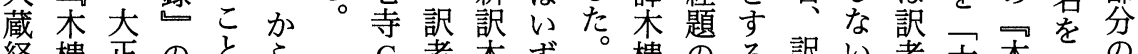
経槵正のとら禇木ず。槵のる訳い者天杰をの

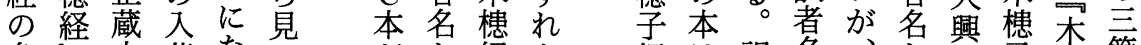

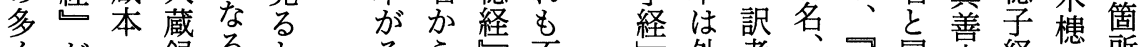

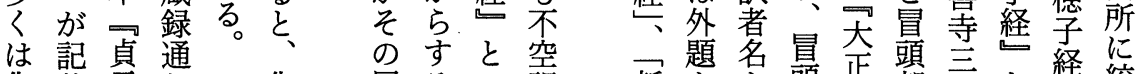

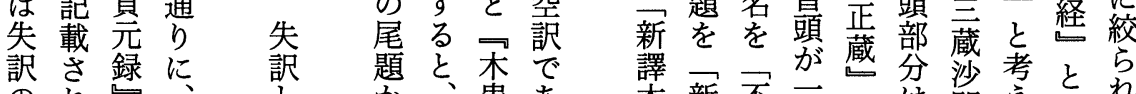

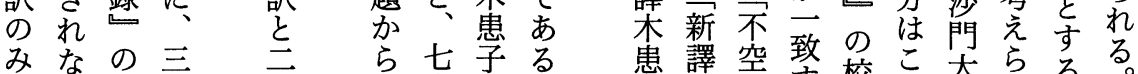

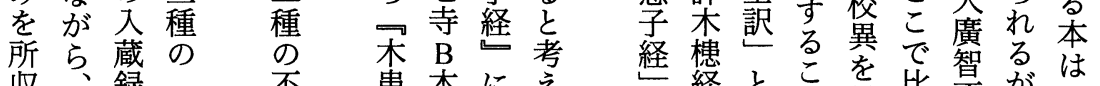

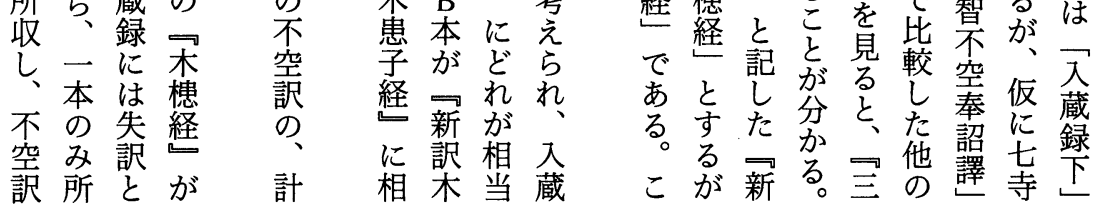


明でる種のなにて同同本と、同訳正を らあ金よとでり、い開で本はと虬本と別も

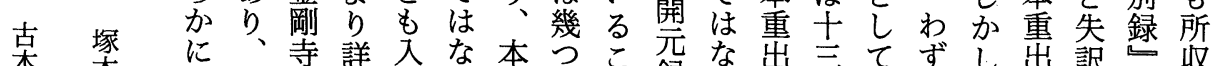
本家

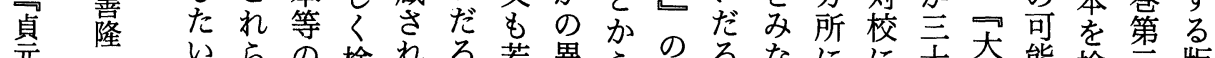

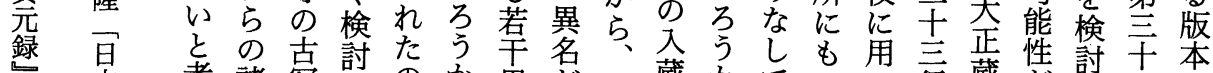

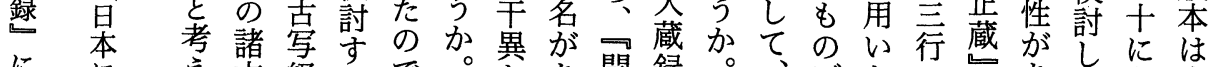

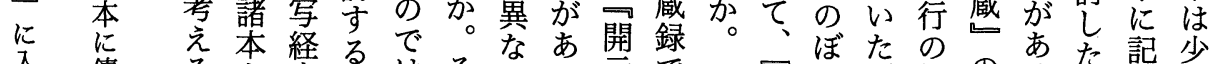

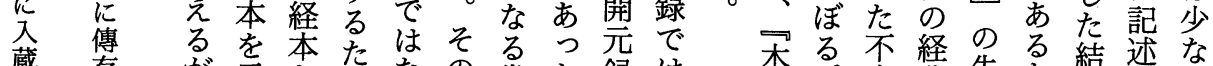

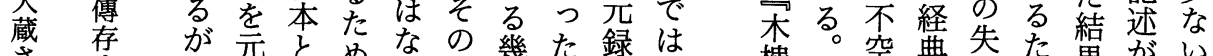

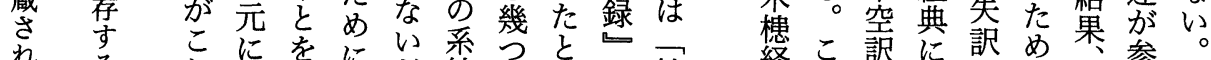

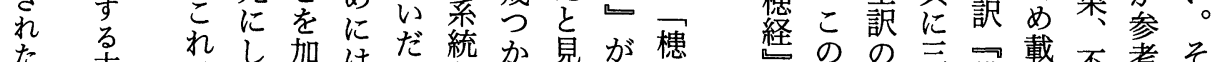

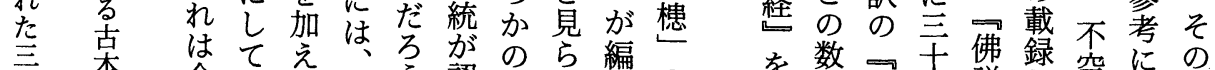

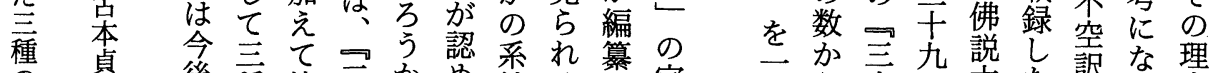

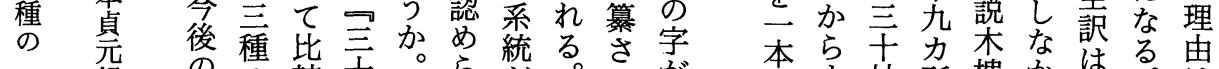

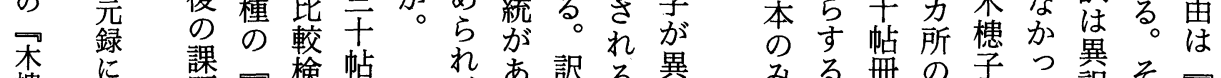

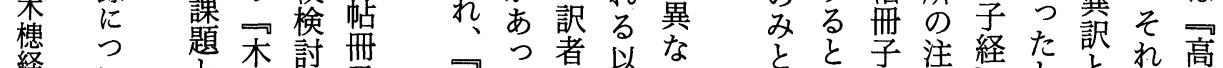

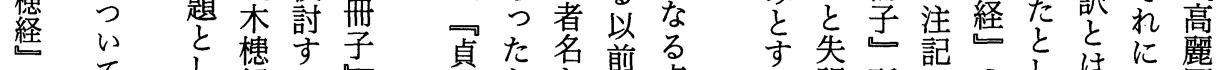

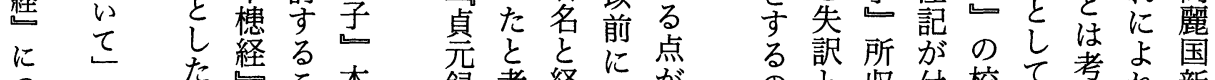

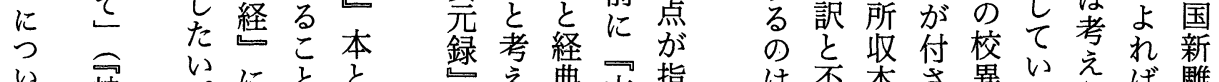

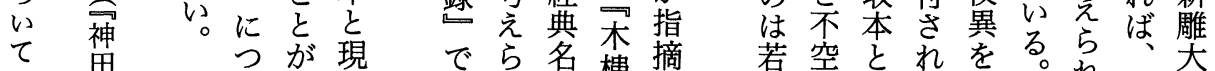

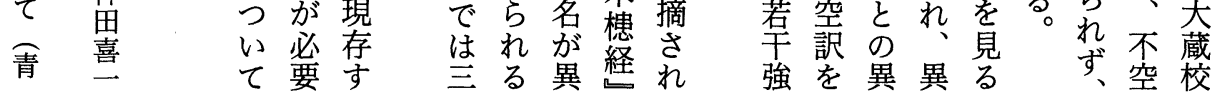
木

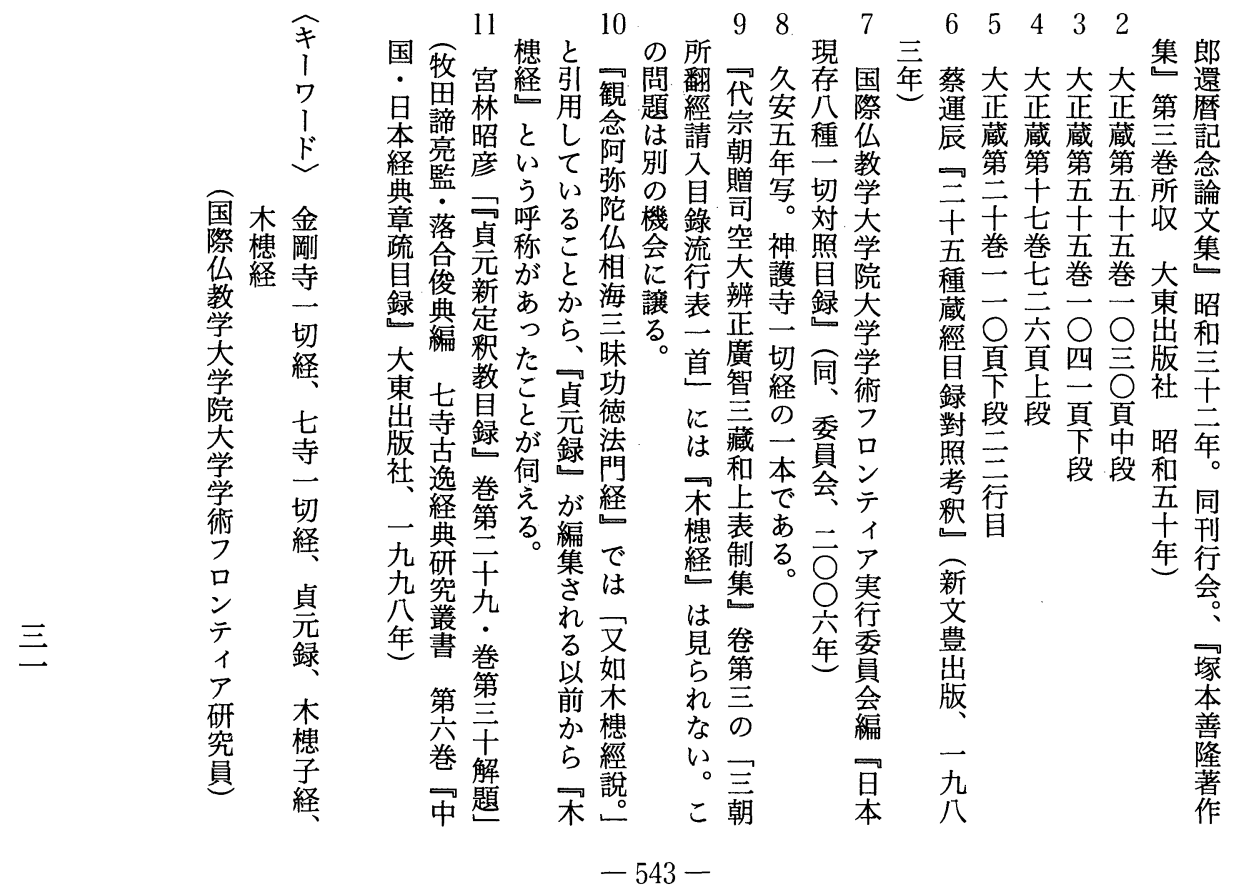


requirements than the usual Śila required by monks. It will be argued, therefore, that the Ugrapariprccha $\bar{a}$ and Jingxing ping of the Huayan jing attempt to define the monastic bodhisattva as a sterner, more disciplined monk.

\section{Hitherto Unknown Manuscripts of the Wuwang-jing (五王経) from Japan}

HAYASHIDERA Shōshun

In this paper, first of all, I clarify differences between a hitherto unknown version of the Wuwang-jing found among old Buddhist manuscripts in Japan and the printed version. There are three differences; 1) the sequence of eight kinds of suffering (duhkha), 2) terminology used, and 3) brevity or details of sentences in the same paragraphs.

Secondly, I examine which versions of the Wuwang-jing were quoted in Buddhist writings in both China and Japan, and found that there were seven occurrences of quotations of the printed version and only one of the manuscript version.

Thirdly, in spite of the above-mentioned differences, a close relationship is presupposed because of the high portion of identical sentences. As far as this is concerned, there are two possibilities. One is to assume that the manuscript version was composed by deleting some sentences from the printed version. Another is quite the opposite, i.e., the printed version was composed by adding some sentences to the manuscript version. Internal textual evidence suggests that the second possibility is more likely. In order to arrive at a definitive conclusion, however, a further and closer examination shall be needed.

\section{On the Three Versions of the Muhuan jing Recorded in the Old Zhenyu- an lu}

AOKI Susumu

The old manuscript of the Zhenyuan $l u$ 古本『貞元録』preserved in the Nanatsu-dera collection, which represents a recension based on the text transmitted to Japan immediately after its compilation, records three versions of the Muhuan jing 『木槵經』. On the other hand, the Taishō recession 
of the Zhenyuan lu registers only two versions of the Muhuan jing. Furthermore, volume 17 of the Taishō Canon contains only one text entitled Muhuan jing.

It would appear that Amoghavajra's translation was considered a similar rendering of the same text, which was not essentially different from the recension attributed to the unknown translator and therefore not used as the basic text of the printed versions.

The Taishō edition of the text, the Fo shuo muhuan jing『佛説木槵子經』, which also adopts the recension attributed to an unknown translator, relies on the text of the Korean Canon, and its footnotes collate it with the variant readings found in the printed versions as well as in Amoghavajra's translation of the Sanjījō sasshi『三十帖冊子』. One is, however, struck by the fact that for a short text consisting of only 33 lines in the Taishō Canon, we have no less than 39 footnotes and 13 variae lectiones different from the Sanjūjo sasshi version. It would thus seem unreasonable to regard the rendering attributed to the unknown translator and Amoghavajra's translation as being similar or identical renderings of the same text.

In this paper, I examine the three versions of the Muhuan jing recorded in the old Zhenyuan $l u$ on the basis of the three Nanatsu-dera manuscripts of the text, copied in the Heian Period.

\section{On the Texts of the Dafo ding bie xingfa 大佛頂別行法}

LIN Min

The text, whose complete title is Da fo ding rulai fangguang xidanduo bandanluo dashenli dushe yiqie zhouwang tuoluoni jing da weide zuisheng jinlun sanmei zhou pin diyi 大佛頂如來放光悉怛多般怛羅大神力都攝一切咒王陀羅 尼經大威德最勝金輪三昧咒品第一, is included in volume 19 of the Taishō Canon (No. 947). This version is based on a manuscript which was copied in year 3 of the Enkyū Era 延久 (1071 C.E.) and belongs to the Sanmitsu Collection三 密藏 of Tō-ji 東寺.

The traditional catalogues of Buddhist scriptures contain no reference to the Dafo ding bie xingfa. We find, however, a total of 14 manuscripts of the text in the Dunhuang collecions. They are complete or partial texts which 